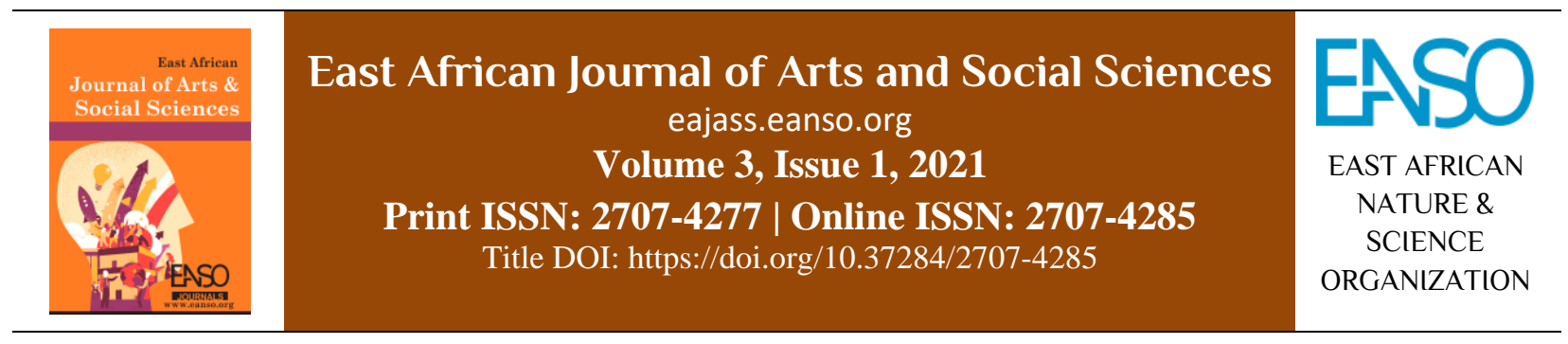

Original Article

\title{
Broadcast Media Entertainment and Attitude Cultivation: A Study of Obscene Programme Viewership by College Students.
}

\author{
Omoniyi F. Akinkoya ${ }^{1}$, Ayo C. Odetoyinbo ${ }^{2}$ \& Taiwo A. Olaniran*3 \\ ${ }^{1}$ Department of Mass Communication, Crawford University, P.M.B. 2001 Igbesa, Ogun State, Nigeria. \\ ${ }^{2}$ Department of Mass Communication, Crescent University, P.M.B. 2104 Abeokuta, Ogun State, Nigeria. \\ ${ }^{3}$ Department of Mass Communication, Ibadan Polytechnic, P.M.B. 22 Oyo State, Nigeria. \\ *Correspondance email : tolaniran@yahoo.com.
}

Article DOI: https://doi.org/10.37284/eajass.3.1.395

\section{Date Published: ABSTRACT}

28 August 2021 This study examined broadcast media entertainment and attitude cultivation, a study of behavioural patterns of College Students. It is a survey designs study that

Keywords: investigated undergraduate communication students of The Polytechnic, Ibadan, Oyo State and Moshood Abiola Polytechnics, Ogun State. Systematic random

Entertainment sampling was adopted to select a sample size of three hundred (300) communication

Programmes, students of the two institutions as respondents for this study. Programmes such as

Nigerian Youth, films, soap operas and musicals, etcetera were units considered. The theoretical

Content/Message, framework is premised on the cultivation theory and gratification theory. Its Attitude analysis was hinged on the simple percentage statistical calculation. The study Cultivation, outcome showed that youth crave satisfaction in the entertainment programmes they watch and that entertainment programmes like musical videos, foreign and local Cultural Norms, drama do portray obscenity which brings about delinquent behaviour in the younger

Values. generation. It was recommended that producers and directors of entertainment products should be conscious of young people who form the chunk of their audience to eliminate obscenity in programme production, while parents should control the level of media exposure of their wards.

\section{APA CITATION}

Akinkoya, O. F., Odetoyinbo, A. C \& Olaniran, T. A. (2021). Broadcast Media Entertainment and Attitude Cultivation: A Study of Obscene Programme Viewership by College Students. East African Journal of Arts and Social Sciences, 3(1),137-146. https://doi.org/10.37284/eajass.3.1.395

\section{CHICAGO CITATION}

Akinkoya, Omoniyi F., Ayo C. Odetoyinbo \& Taiwo A. Olaniran. 2021. "Broadcast Media Entertainment and Attitude Cultivation: A Study of Obscene Programme Viewership by College Students". East African Journal of Arts and Social Sciences 3 (1), 137-146. https://doi.org/10.37284/eajass.3.1.395.

137 | This work is licensed under a Creative Commons Attribution 4.0 International License. 


\section{HARVARD CITATION}

Akinkoya, O. F., Odetoyinbo, A. C. \& Olaniran, T. A. (2021) "Broadcast Media Entertainment and Attitude Cultivation: A Study of Obscene Programme Viewership by College Students”, East African Journal of Arts and Social Sciences, 3(1), pp. 137-146. doi: 10.37284/eajass.3.1.395.

\section{IEEE CITATION}

O. F. Akinkoya, A. C. Odetoyinbo, \& T. A. Olaniran. "Broadcast Media Entertainment and Attitude Cultivation: A Study of Obscene Programme Viewership by College Students”, EAJASS, vol. 3, no. 1, pp. 137-146, Aug. 2021.

\section{MLA CITATION}

Akinkoya, Omoniyi F., Ayo C. Odetoyinbo \& Taiwo A. Olaniran. "Broadcast Media Entertainment and Attitude Cultivation: A Study of Obscene Programme Viewership by College Students". East African Journal of Arts and Social Sciences, Vol. 3, no. 1, Aug. 2021, pp. 137-146, doi:10.37284/eajass.3.1.395.

\section{INTRODUCTION}

Communication, because of its ubiquitous nature in human existence is the mother of all subjects. Hence, it is a phenomenon in all ramifications mostly used, unused and over-used. It is what initiates words in the form of messages of any kind while at the same time, gives meaning to them. Therefore, communication is everything and viceversa. Communication has given rise to "media" which is now used in various forms, metamorphosing into the one now referred to as "new media". From observation, the new media enhanced by modern technologies have digitised all forms of media, especially bringing to bear the convergence of the 'old' or 'mainstream' electronic media (radio and television).

The global media is mainly dominated by five major companies -Time Warner, News Corp., VIACOM, Vivendi Universal and Walt Disney. Even in the information age ushered by globalisation, the major chunk of media messages - news, films, music, animation, other ranges of entertainment are influenced by the big five. Media in other climes are largely influenced by the activities of these media giants whose major agenda is profit-making and perpetuation of the ideologies of the owners and their affiliates.

\section{Statement of Problem}

The media plays a huge role in our everyday life and it affects the way we think and act. Digitisation of broadcasting has freed up more production, transmission and reception space for media messages. Hence, in the information age we live in, entertainment messages in different programme designs of films, music, soap opera, games, reality shows, animation, and etcetera are having a detrimental influence on the younger generation.

Mughal (2013) declares that we put our trust in the media as an authority to give us news, entertainment and education. He, however, retorts that the influence of the media on our kids, teenagers and society is so big that we should know how it really works. Media entertainment with its lewd and violent contents does influence socio-cultural norms and values. It is apropos to examine the influence of entertainment media messages and attitude cultivation of the Nigerian youth vis-a-vis the degeneration into delinquent behaviours occasioned by media entertainment programmes on TV. The objectives of the study were to identify major entertainment programmes type that youth watch; to find out whether the entertainment programmes content expose the youths to delinquent behaviours in regards to obscenity; to ascertain whether youths crave satisfaction in the entertainment programmes they watch; to identify the ways of containing the negative influence of entertainment programmes. The following questions were put forth and answered in this study:

- Which prominent programmes do youth watch on TV?

- Do the entertainment programmes content expose the youths to delinquent behaviours in regards to obscenity?

- Do the youths crave satisfaction in the entertainment programmes they watch?

- What is the way of containing the negative influence of entertainment programmes? 


\section{LITERATURE REVIEW}

\section{Mass Media (Broadcasting)}

The various inventions of modern technological breakthroughs have given rise to the various innovations leading to the digitisation of modern mass media of communication equipment and facilities. It has also given rise to media convergence, miniaturisation and compression of all sorts of media facilities in the electronic mechanism process and devices the world over. Mass communication of which majorly information and messages are passed through the 'screen' or 'tube' (television, cell phone, computer, etc.), is gradually becoming a thing of the past since individual viewership is nowadays paramount. Hence, broadcasting generally has taken over as a form of window through which all other communication types exhibit themselves. It is no more limited to the old forms of radio and television, stations on land (terrestrial) but very well now involves satellite which transmits from space directly to the earth stations which, in return, subscribes or hires the spaces provided.

From observation, these satellite transmission providers such as DSTV, CONSAT, GOTV, MITV and JOY TV, to mention but a few, have taken over old broadcast media communication, especially television stations on land. Many subscribe to the satellite station not as 'public or mass' broadcast but as 'narrow' casting (Walters, 1994 and Bignell, 2008). This new trend has been due to the convergence whereby the word 'media' is now used to mean all communication avenues. It is in the vein that Oso (2012, p. 7) discloses that "with digitalisation and convergence, a cell phone, for example, can be used to perform multiple functions: receiving and sending both voice and text messages, photographs, music and other forms of entertainment, news..." Thus, this has generated a kind of multi-platform avenue for content sharing by all media gadgets and facilities (Odetoyinbo, 2012).

The presence and usage of satellites have brought to the fore the important role and of course, the influence of the media in information dissemination, thereby broadcasting the horizons of the audience and in return shaping their mindsets.
Thus, the attending global information and interaction (internet system) have brought about cross-cultural communication. This has resulted in the delivery and infiltration of electronic products, which have bypassed both physical and political constraints. This era of digitalisation enhances globalisation and the transfer of western culture to the traditional societies of Africa, eroding the latter's cultural autonomy and political sovereignty. In this disclosure about the message of the media, Odetoyinbo (2001, p. 45) citing Uyo (1987) subjects that "it broadens and deepens one's perspectives; it persuades, sells goods and services and promotes candidates and public opinions; it entertains; it creates laughter; it fills a void, and it costs money and it makes money."

Likewise, one of the functions of communication (media) performs, as given by Lasswell cited by Daramola (2003) as contained in Anaeto, Onabajo, and Osifeso (2008, p. 25), is "transmission of cultural heritage from one generation to the other," while Wright (1975) adds entertainment as cited by Odetoyinbo (2005). From observation, these connote entertainment programmes or contents such as films (drama), musicals and festivals which reflect the cultural heritage (norms and values) of the environment. Therefore, the media as it were, have an important role to play, and of course, influence the socio-cultural process and wellbeing of any society.

\section{Socio-cultural Environment}

The average Nigerian socio-cultural environment is somehow bipolarised. There is the 'old school' and the 'new school' - the former, the conservatives (older generation) and the latter (younger generation - 'Youth'). From observation, the local sociocultural norms and values have not been totally eradicated despite the proliferation of entertainment programmes (film (drama), musicals, etc.). The traditional tenets still tend to dictate the behavioural patterns and at times serve as checks on the excesses of the individuals in the society.

This brings to the fore the socialisation process which has the family, institutions (education/governmental), the peer groups (clubs, associations, etc.) and the religions. "Charity begins at home", they say, but nowadays, the 
communication cues from various homes, though polluted too, in the family socialisation process due to the complexities from the society generally in terms of means of survival. Generally, Nigerians are saddled with challenges of the unfriendly economic environment; hence, the media, from observation, tend to serve as respite and replacement for the dictates of the socialisation process. Thus, there is no clear-cut socialisation process that will shape the behavioural patterns of the average Nigerian youth. Every one of them, because of their vulnerability to media content, tends to follow what comes out of the screen.

It is in this vein that McQuail (2010, p. 492-3), caught in the argument of the role of media in family socialisation, posits that "thesis of media socialisation has, in fact, two sides to it: on the one hand, the media can reinforce and support other agencies of socialisation; on the other, they are also viewed as a potential threat to the values set by parents, educators, and other agents of social control". He further contends that the content of media with the largest audiences does appear broadly supportive of reigning social norms and conventions (an aspect of socialisation and of 'culturation').

The implication of these submissions is that the dominant media audience as in the case of satellite media (narrow) paid to cast tends to be more affected and influenced by their contents (messages), and in the end, put into practice these contents. From observation, has this situation been responsible for the youths' behavioural pattern as dictated by the contents (drama, musicals, etc.) of satellite media (DSTV and others, social media, cell phones, etc.)?

\section{Television Effect}

Television (screen/tube) viewing from observation nowadays has gone a long way in the determination and shaping the society's cultural norms, values and trends of lifestyles. This has been made very possible due to the digitisation today as 'new media'. It has also brought about the convergence of all communication types involving radio, television, cell phones, internet, to mention but a few. It is in this regard that Vivian (2009, p. 81) citing Novak who in his comments about the power of television that not only is a "moulder of the soul's geography but builds up incrementally a psychic structure of expectations." Thus, it is a medium one time referred to as the "devil's box". Adekanmbi (2006, 191) echoing the powerful nature of television, contends that "...one of the most, potent tools for mass mobilisation... is a potent instrument of manipulation, a mighty weapon of conquering minds."

However, Fiske (1991, p. 56) in determining the influence of television put forward two schools of thought. The theoretical approach of representation which has to do with television's construction of reality that is "what it misrepresents or mystifies is its own ideological practice", while the mimetic approach critique television's “photography's deviation from or replacement of an absolute truth and its critical comparisons are with truer, more accurate images of the real." Fiske (1991, p. 56) further sums it up that both approaches in one way or the other argue that the camera is an agent of misrepresentation. Thus, they both, in the end, opposed to the general view of perception that the camera cannot lie; but arguing "that the camera does nothing but lie." Therefore, from observation, it is in this regard that filmmakers pre-view at the end of a film, "The making" of the film. This usually showcases violent and obscene movements and actions in order to disprove such plots and make them appear untrue to the audience.

The new media as it were, have the tube or screen (television) as the window in showcasing realities of happenings around. McQuail (2010, p. 496) reveals that the early cultivation research finding of Gerbner and Gross (1976) corroborated by Romer et al. (2003) has it that "the more television people viewed, the more likely they were to exaggerate the incidence of crime in the real world and the personal risks they run." He further crowns it all that "...the more time a person spends watching television (of all kinds), the more he or she will adopt the predominant outlook of the world that is expressed on the medium" (McQuail, 2010, p. 496).

Thus, the rate at which the Nigerian youths are exposed to television in many forms nowadays, learning and interacting with all sorts of information and message ranging from entertainment (musicals, films (drama), news on violence, obscenities) to 
mention but a few, is observed to be alarming. The cheap and easily accessible facilities are said to be responsible for this. This spate tends to erode the standard of the average Nigerian cultural norms and values.

\section{Entertainment Effects}

Entertainment today has made the media to be so popular and has many effects aside from the unforeseen negative consequences (McQuail, 2010, p. 499 citing Zillmann and Bryant 1994). Further citing Knobloch and Zillmann (2002), McQuail argues that entertainment can be considered as; having such effects as "...amused, emotionally aroused so as to experience sadness, happiness, anger, relief, excitement, fear, etc., diverted from anxiety and so on. Music has also been credited with a number of effects, especially on moods and dispositions and on arousal".

Zillmann (1980) as further revealed by McQuail (2010, p. 499), identifies: “...the appeal of drama in terms of enjoyment and annoyance induced by the changing fortunes of positively or negatively portrayed characters." Thus, the social and cultural influence of the media cannot be underestimated in this era of media convergence enhanced by digitalisation. However, as contended by McQuail (2010, p. 500), "the media are unlikely to be the main driving forces of fundamental long-term change, although consequences of increasingly rapid and penetrating diffusion of information, ideas and images on a global scale should not be underestimated". This, of course, are many of the probing issues this research work is contemplating to find out as the average Nigerian youth is concerned in today's world of the rapid growth of entertainment content and accessibility.

\section{THEORETICAL FRAMEWORK}

The digitisation of the media has brought about the convergence of all facets of communication, making all of them have links or pitches tent with electronic mechanism process and device, thus, making the screen or tube the window for all. This, therefore, brings to the fore the powerful nature of the modern media because digitisation has brought about wonderful tunes to all and sundry. Hence, messages from these media create a kind of stimulus-response to the audience. It is to this background that Folarin (1998, p. 59), revealing one of the assumptions of Stimulus-Response (S-R) theory, says that the theory "greatly influences and sways people's minds; especially with the use of emotional appeals." It is therefore on this premise that this research work considers the following theories - Agenda Setting, Cultivation, and Uses and Gratification.

\section{Cultivation Theory}

It is propounded by George Garbner, L. Gross, M. Morgan and N. Signorielli in 1976 (Anaeto et al., 2008). The theory postulates that "heavy TV viewers will cultivate the perception of reality portrayed by the television; and thereby predicate their judgement and actions on the cultivated reality dictated by television." (Anaeto et al., 2008, p. 103). Others' assumptions are that television creates a forum in which people can interact which makes it different from other media. Television tends to stabilise social patterns and thereby majorly a medium of socialisation and acculturation (Anaeto et al., 2008, p. 104). This is the central focus of this study to examine the extent to which the average Nigerian youth cultivate the content reality of the 'things' they watch on television and to what extent are these contents being shared among other youths.

\section{Uses and Gratification Theory}

A theory propounded by Slihu Katz, Jay Blumler, and Michael Gurevitch in 1974 as cited by Folarin (1998), Anaeto et al. (2008) and Balnaves et al. (2009). Some of the paradigms are that a media user who needs communication selects the media which is likely to satisfy those needs. Hence, the selection is based on the consumption of the contents such as entertainment, relaxation, knowledge acquisition and so on (Folarin, 1998, p. 65). He further brings forward Kunczik (1988, p. 176) argument that "an effect may or may not occur" (Folarin, 1998, p. 65). It is in this vein that Balnaves et al. (2009, p. 73) comment that some researchers on media effects assume that "... the audience is active, not passive that it might for example be concerned with the credibility of the media; its type of content and the attention it pays to a particular type of content, ..." 
Thus, this assumption from observation on the issue of agenda-setting tends to run contrary to it. The media have the power to give prominence, salience and persistent 'colouring' and exposure of some aspects of their content /message. This will, in the fullness of the media, tend to make such the vogue (norms /values) and thereby influence the audience to cultivate. This research work hopefully tends to find out how this is relevant to the situation of the Nigerian youth, especially those in the higher institutions as represented by Mass Communication students of the two polytechnic institutions chosen.

\section{METHOD OF DATA COLLECTION}

This study employed the survey research design. Purposive and systematic random sampling techniques were used for the study. Senior-level mass communication students of two tertiary institutions in the south-west, Nigeria (the Polytechnic, Ibadan, Oyo State and Moshood Abiola Polytechnic, Ogun state) were purposively selected for this study. The two institutions are government-owned and were established in 1970 and 1979, respectively. Systematic random sampling was adopted to select three hundred (300) respondents from Mass communication students in Higher National Diploma (HND) I and II levels from the two schools.

Questionnaires were used to gather the data. 300 questionnaires were sent out, but 296 of them were properly filled and returned. Simple percentages and frequency tables were employed to analyse the data gathered. $28 \%$ of the respondents were males and $72 \%$ were females. $53 \%$ fell in between 26-30 age brackets, $24 \%$ were in the $21-25$ range, $8 \%$ made under 20 categories, while $15 \%$ of the respondents were above 30 years of age. On marital status, $92 \%$ were single and $8 \%$ were married. The entertainment programme categories used for this study are local drama (films, soap operas, etc.), foreign drama (films, soap operas, etc.), musical videos, sport, documentary, news, cartoon, others.

\section{RESULTS}

Research Question one: Which prominent entertainment programmes do youth watch on TV?

Table 1: Frequency of Programmes Youth Watch on Tv

\begin{tabular}{lll}
\hline Categories & Frequency & \% \\
\hline Drama (Local) & 73 & $25 \%$ \\
Drama (Foreign) & 46 & $15 \%$ \\
Sport & 57 & $19 \%$ \\
News & 20 & $7 \%$ \\
Musical Video & 62 & $21 \%$ \\
Cartoon & 10 & $3 \%$ \\
Documentary & 23 & $8 \%$ \\
Others & 05 & $2 \%$ \\
Total & $\mathbf{2 9 6}$ & $\mathbf{1 0 0}$ \\
\hline
\end{tabular}

Table 1 shows that $25 \%$ (73) of the respondents declared that local drama (films, soap operas) is their most prominent entertainment programme. $21 \%$ (62) stated that most music videos is their prominent entertainment programme. $19 \%$ (57) and $15 \%$ (46) said sports and foreign drama respectively. Mere $8 \%(23), 7 \%$ (20) and 3\% (10) make an indication to documentary, news and cartoon respectively, while $2 \%$ (5) pointed to other programmes. Hence, local drama is the most prominent entertainment programme followed by music videos, sports and foreign drama in that order. News and documentary are among the least prominent programmes.

Research Question Two: Which
entertainment programme contents expose the
youth more to delinquent behaviours in
regards to obscenity?


Table 2: Delinquency Due to Obscene Programme Contents

\begin{tabular}{lll}
\hline Programme Type & Frequency & \% \\
\hline Drama (Local) & 67 & $22.6 \%$ \\
Drama (Foreign) & 74 & $25 \%$ \\
Sport & 45 & $15.2 \%$ \\
News & 8 & $2.7 \%$ \\
Musical Video & 92 & $31 \%$ \\
Cartoon & - & - \\
Documentary & - & - \\
Others & 10 & 3.4 \\
Total & $\mathbf{2 9 6}$ & $\mathbf{1 0 0}$ \\
\hline
\end{tabular}

As shown in table 2, 31\% (92), 25\% (74), and $22.6 \%$ (67) of the respondents agreed that musical video, foreign drama, and local drama respectively purvey obscene content, while $15.2 \%$ (45) agreed that sport contains obscenity. It shows therefore that musical video, foreign drama and local drama in that order purvey obscene content with the larger percentage of the youth (respondents) being exposed to them and potentially leading to delinquent behaviours.

Research Question Three: Do the youths crave satisfaction in the entertainment programmes they watch?

Table 3: Youth Craving Satisfaction in Entertainment Programme

\begin{tabular}{lll}
\hline Categories & Frequency & \% \\
\hline Yes & 261 & 88.2 \\
No & 35 & 11.82 \\
Total & $\mathbf{2 9 6}$ & $\mathbf{1 0 0}$ \\
\hline
\end{tabular}

Table 3 however shows that $64 \%$ (190) and 25\% (75) of the respondents agreed and strongly agreed that they crave satisfaction and pleasure in the entertainment programmes they watch. Only $8 \%$ (25) and 3\% (10) strongly disagreed and disagreed, respectively. Those that agreed and strongly agreed added up to $89 \%$ which shows that youth crave satisfaction in the entertainment programme they watch.

Research Question Four: What is the way of containing the negative influence of entertainment programmes?

Table 4: Ways of Containing Negative Influence of Entertainment Programme

\begin{tabular}{lll}
\hline Containing Negative Programme Influence & Frequency & \% \\
\hline Broadcast Ownership Control & 10 & $20 \%$ \\
Ethical Control (Producers/Directors) & 86 & $29 \%$ \\
Individual Caution/Discipline & 59 & $20 \%$ \\
NBC Censorship & 50 & $17 \%$ \\
Parental Guide & 62 & $21 \%$ \\
Religious Group Counselling & 29 & $10 \%$ \\
Total & $\mathbf{2 9 6}$ & $\mathbf{1 0 0}$ \\
\hline
\end{tabular}

Table 4 shows the opinion of the respondents on the ways of controlling the negative influence of entertainment programmes on TV. 29\% (86) of the respondents agreed that having ethical regulations to guide the productions of producers and directors is critical to mitigating the negative influence of digitised broadcast entertainment media content. $21 \%$ (62) of the respondents put the solution at the

143 This work is licensed under a Creative Commons Attribution 4.0 International License. 
doorstep of parents to guide and control what their children/wards watch. Another 20\% (59) of the respondents, however, agreed that individual caution and discipline plays an important role in containing the negative influence of entertainment programme. $17 \%$ (50) of the respondents, however, maintained that Government censorship of broadcasting in Nigeria through the National Broadcasting Commission (NBC) will still help to curtail the negative influence of entertainment programmes contents. $10 \%$ (29) posited that religious group counselling is also another means of tackling the challenge, just as $3 \%$ of the respondents are making a call to the Broadcast owner to control the contents of programmes.

\section{DISCUSSION OF FINDINGS}

\section{Research Question One}

According to this study, local drama is tops on the list of prominent entertainment programmes. This may not be far-fetched owing to the noticeable role of the Nigerian film industry. The recognition given to Nollywood in recent times coupled with a high number of home videos being churned out weekly by Nollywood producers and directors has increased the volume of video availability and attracted a keen audience home and abroad.

The music video is next to local drama on prominence. The music industry globally in recent times has witnessed an explosion in terms of social, economic and technological integration. It is a huge market in the entertainment industry at the production, transmission, marketing and consumption stages.

\section{Research Question Two}

This study reveals that musical videos, foreign drama and local drama contain obscene, salacious and violent acts which could lead to delinquent behaviours. The popular culture in Western societies like free sexual orientation, same-sex relationships, open sex display, among others, have become an integral part of their film and music industry and at times, the core reason. The local entertainment industry is taking a cue from the entertainment industry of the West. The morally deficient musical videos and home videos in the market bear witness to this position. The digitalisation of the broadcast industry has also made media content of many foreign channels easily accessible to many homes on satellite TV platforms.

Apart from foreign drama and musical video, local drama sharply leads to the abuse of cultural norms and values among entertainment programmes. This further asserts the submission of Udomisor and Sonuga (2012:33) that "despite the international attention currently received by Nollywood, the quality of its productions and the contents of its stories are still issues that need to be worked on" and that "some critics both local and international see the Nigeria film industry as a poor imitation of the real thing". It must be stated that the Nigerian film industry is misrepresenting cultural values and norms in regards to fetish endeavours, abuse of traditional and religious tenets, disrespect, etc., and it is superimposing foreign cultures on local values. Mediocrity, salacity and vulgarity are now the selling propositions in the entertainment industry.

This study was able to establish that entertainment programmes do bring about delinquent behaviours, as affirmed by the majority of the respondents. This strengthens the position of the cultivation theory by George Garbner et al. that "heavy TV viewers will cultivate the perception of reality portrayed by the television; and thereby predicate their judgement and actions on the cultivated reality dictated by television. (Anaeto et al. 2008, p. 103)

\section{Research Question Three}

The study outcome also confirms that youth crave satisfaction in the entertainment programmes they watch. This has in a way linked the production of media content to the market forces rather than the source (producers). Tom Gunning in his online paper agrees that "the primary purpose behind most commercial films, of course, was to make a profit and any film that wanted to attract and keep audience had to be appealing and entertaining".

Kayode (2014, p. 281-282) corroborates this assertion when he states that "...media audiences generally are most interested in stories which contain the elements most dominant in their primitive emotions, namely: 
- Self-preservation: Under this heading come stories of murder, suicide, rescues, accidents, fights, facts as to health, food, liquor, etc.;

- Love or reproduction: This element is contained in stories of marriage, scandal, divorce, human triangles, romances, unusual acts done with love motive, jealousy, sex attraction, etc.;

- Ambition: The ambition element is contained in articles tending to stimulate the reader to emulate the activity of a character in the story. Sports come under this classification.

\section{Research Question Four}

The study outcome shows that the media audience is of the opinion that there need to be in place ethical regulations to control producers and directors in the production of media entertainment messages that are for the common good of the society. In the same vein, parental guide and control with the selfdiscipline by the users of mass media on their exposure to media messages will play a key role in controlling the negative impact of media messages.

The role of the government and that of its broadcast regulatory body- NBC also find relevance in this study. NBC has the mandate to license media ownership, control and regulates broadcast media programme content of TV and radio stations in the country. For quite some time, the body has become a dumb and toothless dog that can neither bark nor bite. It needs to be actively alive to its regulatory role.

\section{CONCLUSION}

The mass media message owing to commercialisation, globalisation and digitisation of broadcasting is now more open, profit-oriented, and pervasive and many at times loaded with lewd content to attract the audience who to some extent also crave such forms of entertainment and pleasure. The government, media regulatory agencies, producers, directors, parents and other stakeholders all have a major role to play in addressing the negative influence of media entertainment messages.

\section{Recommendations}

- Producers and directors of entertainment products should be mindful of giving proper representation to cultural norms and values and promote in the content of their productions that serve the greater good of the society.

- Parents should guide and control the nature and level of media entertainment their wards are exposed to dutifully. Socio-economic pressure should not make them abandon their primary role of parenting.

- The Federal Government should muster the political will to develop a framework for the National Broadcasting Commission (NBC) and National Information and Communication Technology Development Agency (NITDA) to work together in fast-tracking the process of digitisation and regulating digital broadcasting in the country, vis-a-vis programme content, transmission and other operational regulations.

\section{REFERENCES}

Adekanmbi, A. (2006). Walking the Tight Rope of Political Control in a State-owned Television Station, in Biodun Odetoyinbo ed. GTV: A Gateway to Broadcast Excellence. Abeokuta: Gbenga Gbesan and Associates Publisher.

Anaeto, S. G., Onabajo, O. S. and Osifeso, J. B. (2008). Models and Theories of Communication. Bowie, Maryland: African Renaissance Books Inc.

Balnaves, M., Donald, S.H. and Shoesmith, B. (2009). Media Theories and Approaches: A Global Perspective. UK: Palgrave MacMillan Publishers.

Bignell, J. (2008). An Introduction to Television Studies (2nd Ed.). New York: Routledge.

Fiske, J. (1991). Postmodernism and television. In J. Curran \& M. Gurevitch, Mass Media and Society. London: Edward Arnold Publisher.

Folarin, B. (1998). Theories of Mass Communication: An Introductory Text. Ibadan: Stirling-Horden Publishers (Nig.) Ltd.

145 | This work is licensed under a Creative Commons Attribution 4.0 International License. 
Gunning, T. "Making Sense of Film" in Making Sense of Evidence Series on History Matters: The US Survey on the Web (http://historymatters.gmu.edu). Retrieved on 27-09-2015.

Kayode, O. (2014). "Ethical challenges of tabloidisation and trivialisation in the Nigeria media space" in Journalism and Media in Nigeria: Context, Issues and Practice. Canada: Canada University Press.

McQuail, D. (2010). Mass Communication Theory (6th Ed). Los Angeles, CA: Sage Publications.

Mughal, M. (2014). Mass Media and Its Influence on Society (www.thedailyjournalist.com/penand-pad/mass-media-and-its-influence-onsociety) Retrieved 27/09/2015.

Odetoyinbo, A. (2001). Principles of Mass Communication. Abeokuta: Primus Prints and Communication Venture.

Odetoyinbo, A. (2012). Digital Broadcast Environment and Production Techniques. Ogun State: Crescent University Press.

Oso, L. (2012). Communication and transformation in digital age. In S. Adeosun, L. Togunwa and G. Raufu (ed.) The Impact of Communication on the Socio-Economic and Political Development of Nigeria. Ogun State: Department of Mass Communication, Moshood Abiola Polytechnic Publication.

Udomisor, I. and Sonuga, A. (2012). Content analysis of programs produced by Nollywood particularly on Africa magic: DSTV, in Journal of Research on Humanities and Social Sciences,2(11). (www.iiste.org)

Vivian, J. (2009). The Media of Mass Communication (9th ed.). Boston, MA

Walters, R. (1994). Broadcast Writing: Principles and Practice (2nd Ed.). USA: McGraw-Hill Inc. 